\title{
Living and Learning Between Canada and Korea: The Academic Experiences and Cultural Challenges of Undergraduate International Exchange Students
}

\author{
Jeong-Ja Kang a and Amy Scott Metcalfe ${ }^{b^{*}}$ \\ ${ }^{a}$ Ministry of Education, Republic of Korea, ${ }^{b}$ Department of Educational Studies, University of British Columbia, \\ Canada \\ *Corresponding author: Email: amy.metcalfe@ubc.ca \\ Address: Department of Educational Studies, University of British Columbia, Vancouver, BC Canada
}

Received 10/4/18; revised 2/25/19; accepted 4/29/19

\section{Introduction}

Many higher education institutions are expanding their academic cross-border mobility programs with the twin imperatives of nurturing students' global awareness and equipping them for future careers. To serve both university and student interests, "study abroad" student exchange programs, which are an official reciprocal academic mobility arrangement initiated and managed by two higher education institutions, have become "a normal option" (Altbach and Teichler 2001,8) that is promoted by universities as part of a comprehensive internationalization strategy (Hudzik 2014; Rhodes, Loberg, and Hubbard 2014; Take and Shoraku 2018). Inbound and out-bound international students are typically understood as long-term students who stay in the host country for more than one year to earn a foreign credential (Zappa-Hollman 2007). However, given the increasing number of short-term, "study abroad" students, we need to investigate the educational practice of international exchange more deeply. Furthermore, this increasing movement across borders merits deeper exploration because of its impact beyond just physical mobility, which includes the transformation of social norms, cultural values, and a sense of belonging (Pike and Sillem 2018; Rizvi and Lingard 2010).

This study focuses on the experiences of short-term, "study abroad" exchange students enrolled in programs offered through reciprocal partnerships between Canadian and Korean universities, as part of a larger investigation of international student exchange policies and in response to rising student mobility between the two countries. The number of outgoing Korean exchange students and incoming international exchange students in Korea increased from 27,897 to 32,196, and from 14,603 to 21,830, respectively, between 2011 and 2013 (S. Lee 2014). In addition, the number of undergraduate exchange students between Canada and Korea has increased as well. The number of Korean students studying in Canada through short-term exchange programs between 2007 and 2014 increased from 733 to 1,391 , while the number of students from Canadian universities studying in Korea through similar short-term exchange programs increased from 114 to 595 (Korean Educational Development Institute [KEDI] 2015).

The experiences of short-term exchange students might be best explored from a different vantage point than that of long-term students due to the variation in the types of institutional support they receive. International exchange programs are officially organized at the institutional level, and the services provided to study abroad students may be less individualized than the supports available to full-program or longer-term international students, including supports relating to relocation and workforce preparation for those students who seek international education as an immigration pathway (Al-Haque 2017; Doyle et al. 2010). For example, an exchange program between Canada and Korea might be "organized" and provide "administrative services" (Altbach \& Teichler 2001, 12) such as accommodation, credit transfer, and tuition fees (Doyle et al. 2010). As well, exchange students have a double identity as an outgoing student from their home institution but simultaneously an incoming student in their host institution, which is different from long-term international students who usually experience only their 
host institution. Juxtaposing narratives of an incoming student versus an outgoing student helps to understand the reasons why students have certain perceptions of material practices in and between their home and host institution. Unveiling hidden norms and curricula in the academic terrains of exchange students, this study demonstrates students' nuanced and complex understandings of their host country and home country.

Exchange students arrive in a foreign country equipped with socio-cultural inheritances and normative academic codes. However, their familiar ideologies and practices collide with the various forms of otherness they meet in the foreign pedagogical space. For example, Canadian exchange students who went to India or Zimbabwe reported "disorientation and anxiety" due to the different expectations and meanings of "time and punctuality" (Razack 2002, 258). Canadian students in Sweden found the different teaching styles frustrating (Brodin 2010). Some Korean students who studied in the US as exchange students complained that their lack of understanding of local contexts was partly a systemic issue because their home institution sent many students to the same host institution, and thus they had more opportunities to socialize with Korean students (Park 2010). What some students interpret as an open space can be seen by others as a bounded sphere. The perceptual interpretations of the new academic space are subject to one's demographic features, intercultural capacity, individual characteristics, and involvement in the foreign terrain (Park 2010).

\section{Theoretical Framework and Methodological Approach}

The theory of social imaginary (Rizvi and Lingard 2010; Taylor 2004) informed our investigation of the academic engagements of Canadian and Korean exchange students. Mobile students participate in global imaginations and practices (Rizvi 2006), as students experience changes in the "way of thinking" that is "shared in a society by ordinary people, the common understandings that make daily practices possible, giving them sense and legitimacy" (Rizvi and Lingard 2010, 34). The theoretical perspective of the social imaginary is useful in exploring students' dynamic international lives in their academic settings in and between their home and host countries because their engagements with foreign terrains are not fixed, but rather are in constant flux between familiar practices and unfamiliar performances. There may be discrepancies between students' imagined life in their host country and their actual experience, which results in diverse responses in how students cope with differences throughout their transcultural journeys.

In conducting this research, we utilized narrative inquiry (Clandinin and Connelly 2000) to provide ample opportunity to learn from students' lived experiences. A narrative approach reflects hermeneutic processes of self that are enmeshed with dialectic negotiations between socially circumscribed norms and individual ideologies (Holstein and Gubrium 2000; Polkinghorne 1988), which we felt was compatible with this study theoretically. As such, narrative inquiry allowed us to consider and construct dynamic vignettes of the impressions of study abroad students in the study, permitting them to reflect upon what they expected prior to their exchange and what they actually experienced.

We selected Canada University (CU, a pseudonym) as a research site because it has collaborated with Korean universities since early 2000. We interviewed nine undergraduate students who went on an academic exchange between $\mathrm{CU}$ and one of four Korean universities (Table 1). Because narrative inquiry permits the exploration of a small number of participants' narratives in-depth, we planned to recruit six to ten participants, selecting them based on their diverse backgrounds. We initially approached a "gatekeeper" at $\mathrm{CU}$ who contacted former exchange students through a listserv so that interested individuals could contact us directly. However, we did not receive any indications of interest through this official method. Yet, CU has one official social networking service (SNS) for incoming exchange students and we were permitted to join the closed community so that we could recruit research participants. In addition, we posted advertisements around the $\mathrm{CU}$ campus and promoted our research online to recruit returnee exchange students. We selected nine participants through purposive sampling by taking individual backgrounds into consideration. All the names 
of participants and universities in this study are pseudonyms, with the Korean Universities named: Hankuk University (HU), Daehan University (DU), Minkuk University (MU), and Palhae University (PU). At least three official interviews were held with each participant (30 interviews in total). Each interview lasted between 90 minutes and two hours. With some participants, however, we conducted additional interviews and met with them in person more times. Demographically, three of the participants were Canadian and six were Korean, although two of the Canadian students were born in Korea. In terms of ethnicity, all participants identified as Asian. All of the participants were proficient in English and Korean.

\section{Table 1: Study participants}

\begin{tabular}{|c|c|c|c|c|c|c|c|}
\hline $\begin{array}{l}\text { Pseudo- } \\
\text { nym }\end{array}$ & $\begin{array}{c}\text { Nationality/ } \\
\text { Birthplace }\end{array}$ & $\begin{array}{l}\text { Home / } \\
\text { Host U }\end{array}$ & $\begin{array}{c}\text { Gender } \\
\text { (Age) }\end{array}$ & $\begin{array}{l}\text { Major } \\
\text { (Minor) }\end{array}$ & $\begin{array}{c}\text { Academic } \\
\text { year }\end{array}$ & $\begin{array}{l}\text { Exchange } \\
\text { period }\end{array}$ & $\begin{array}{c}\text { Previous foreign } \\
\text { experience }\end{array}$ \\
\hline Angela & $\begin{array}{l}\text { Canada } \\
\text { / China }\end{array}$ & $\mathrm{CU} / \mathrm{HU}$ & $\begin{array}{c}\text { Female } \\
(21)\end{array}$ & $\begin{array}{c}\text { Political Science } \\
\text { (International } \\
\text { Relations) }\end{array}$ & $5^{\text {th }}$ year & $\begin{array}{l}\text { SEP } 2013 \\
\text { JUN } 2014\end{array}$ & US, Asia \\
\hline Erica & $\begin{array}{l}\text { Canada } \\
\text { / Korea }\end{array}$ & CU/HU & $\begin{array}{l}\text { Female } \\
(23)\end{array}$ & Psychology & $\begin{array}{l}\text { Graduated } \\
\text { in } 2014\end{array}$ & $\begin{array}{l}\text { SEP } 2011 \\
\text { AUG } 2012\end{array}$ & US, Asia \\
\hline Shinbi & Korea & $\mathrm{HU} / \mathrm{CU}$ & $\begin{array}{c}\text { Female } \\
(21)\end{array}$ & $\begin{array}{c}\text { Economics } \\
\text { (Chinese Literature) }\end{array}$ & $4^{\text {th }}$ year & $\begin{array}{l}\text { SEP } 2014 \\
\text { APR } 2015\end{array}$ & Europe, Asia \\
\hline Bella & Korea & $\mathrm{PU} / \mathrm{CU}$ & $\begin{array}{c}\text { Female } \\
(27)\end{array}$ & $\begin{array}{c}\text { Business } \\
\text { Administration }\end{array}$ & $\begin{array}{l}\text { Graduated } \\
\text { in } 2012\end{array}$ & $\begin{array}{l}\text { SEP } 2011 \\
\text { DEC } 2011\end{array}$ & China \\
\hline Katy & $\begin{array}{l}\text { Canada } \\
\text { / Korea }\end{array}$ & $\mathrm{CU} / \mathrm{HU}$ & $\begin{array}{l}\text { Female } \\
\text { (24) }\end{array}$ & $\begin{array}{c}\text { Commerce } \\
\text { (Human Resources) }\end{array}$ & $3^{\text {rd }}$ year & $\begin{array}{l}\text { SEP } 2015 \\
\text { DEC } 2015\end{array}$ & US, Europe \\
\hline Sarang & Korea & MU/CU & $\begin{array}{c}\text { Female } \\
(21)\end{array}$ & $\begin{array}{l}\text { English Education } \\
\text { (Economics) }\end{array}$ & $2^{\text {nd }}$ year & $\begin{array}{l}\text { SEP } 2015 \\
\text { DEC } 2015\end{array}$ & Asia \\
\hline Haram & Korea & $\mathrm{DU} / \mathrm{CU}$ & $\begin{array}{c}\text { Female } \\
(21)\end{array}$ & English Literature & $3^{\text {rd }}$ year & $\begin{array}{l}\text { SEP } 2015 \\
\text { DEC } 2015\end{array}$ & Africa, Asia \\
\hline Maru & Korea & $\mathrm{MU} / \mathrm{CU}$ & $\begin{array}{l}\text { Male } \\
(27)\end{array}$ & $\begin{array}{c}\text { Psychology } \\
\text { (Business } \\
\text { Administration) }\end{array}$ & $4^{\text {th }}$ year & $\begin{array}{l}\text { SEP } 2015 \\
\text { DEC } 2015\end{array}$ & US, Asia \\
\hline Gangin & Korea & $\mathrm{DU} / \mathrm{CU}$ & $\begin{array}{l}\text { Male } \\
(25)\end{array}$ & Applied Statistics & $3^{\text {rd }}$ year & $\begin{array}{l}\text { SEP } 2015 \\
\text { DEC } 2015\end{array}$ & $\begin{array}{c}\text { New Zealand, US, } \\
\text { Asia, Europe }\end{array}$ \\
\hline
\end{tabular}

To analyze the data we mainly drew on Riessman's (2008) scalar stages of thematic analysis, focusing on "what' is said" (53) and trying to interpret it within the broad socio-cultural contexts (Grbich 2013; Gubrium and Holstein 2009). We analyzed the data inductively to find recurrent themes. Through these "relentless rereading" (Clandinin and Connelly 2000, 131) processes, we selected categories of data that fell at the intersection of theoretical landscapes and the attributes that had emerged from the accumulated information and stories (Polkinghorne 1995). However, to ensure the trustworthiness of this study, we were cognizant of the blurry boundaries and overlapping areas of criteria, including nationality (with most students in the study sharing Korean heritage regardless of their citizenship) and gender (as the majority of the student participants identified as female). Thus, instead of juxtaposing narratives of Canadian students versus Korean students, 
and female students versus male students, we tried to thickly describe their diverse backgrounds and their unique narratives in detail in order to provide a broader and enriched vignette of the apprehensions, imaginations, and hopes of each student.

\section{Findings}

In contrast to their idealized or imagined exchange program, and in spite of their previous participation in international travel, the nine exchange students in the study viewed their foreign exchange as distressingly unfamiliar. When they found themselves in challenging situations, they tried to make sense of them from their own perspectives and in relation to what they thought they would encounter. In this paper we describe two inter-related aspects of their experiences: academic expectations and interactions with professors.

\section{Collision of different academic expectations, practices, and norms}

At the time of the study, Haram was a third year English Literature major at DU in Korea, about to undertake an academic exchange in Canada at CU. When we first met Haram before her exchange, she had very high expectations for her foreign academic life. Because she is very proficient in English, she was not concerned about her language capacity at a Canadian university. She visualized her future life in Canada as an optimistic portrait of friendly classmates, an amusing class atmosphere, and considerate professors. Yet, when we interviewed her during her exchange, she related that her imagined academic space differed quite significantly from her lived experiences, particularly in relation to her language capabilities. She noted:

In Korea, international students have different types of student ID numbers, so Korean professors already know who the exchange students are. Besides, there are fewer international students in Korea than here. Since I thought the professor would know that I am an exchange student, I was very embarrassed and shocked when he criticized my mid-term exam essay very severely. $\mathrm{He}$ wrote in my essay, "Your own thoughts are not included in your essay fully, but you only paraphrased what I said in the class. Visit me to discuss about this issue." So I went to his office. The professor read my essay aloud from the beginning to the end. And he pointed out every mistake that I made. That's when I realized that he had not known that I'm an exchange student. When I talked about my challenging situation in the literature class with my mom, she said, if I am too stressed then I should just drop the course because she wants me to enjoy new experiences instead of being stressed out due to academic hassles. But when I heard my mom's advice, I disagreed with her: "How can I give up even though I did not yet try my best?" But when I started writing my other term paper, I realized that I could not do it anymore. I did not have enough time to read all the references. On the reading list, there were more than one hundred references. But I don't have enough information about Western contexts, so I don't have any idea what to read. In Korea, some professors ask us to write an English paper, but we don't have to use a lot of references. Even though I would spend another one or two months in this course, I realized that I would never pass this course. Since two months had already passed, I could not withdraw from it anymore so I just dropped the course. I will receive an $\mathrm{F}$ grade in this course.

Since Haram studied abroad beforehand, she did not consider going on an exchange would be an academic hardship for her. Haram felt she was good at English and did not have any problems taking upper level English courses in Korea, therefore she did not have concerns about her language abilities. However, she struggled to keep up in terms of the socio-cultural background necessary to fully comprehend certain types of English literature. In addition, in Haram's experience, in Korea, professors would introduce the background and contexts, explicitly conveying the implicit meanings of the course materials. Because Haram was familiar with this kind of 
"clear" and "organized" lecture style, she viewed Canadian academic practices as too demanding, and she felt disoriented. Her lack of familiarity with Western academic and English literature contexts discouraged her from being actively involved in the class, resulting in a failing grade during her limited term exchange.

In the Korean academic space, taking notes diligently during class and remembering essential points from what the professor talked about are considered sincere engagements with the class. Recent research on the top one percent of Korean university students, that is, those with an A+ average for the previous two semesters, showed that high performing students accurately wrote down what their professors said and then replicated these sentences verbatim in exams (H. Lee 2014). However, in the Canadian academic space exchange students are expected to analyze beyond what a professor teaches, which is less common in Korean educational practices, where students are given credit for scrupulously inscribing the teachers' lessons.

In contrast to Haram's experience, Sarang (a secondyear exchange student at $\mathrm{CU}$ from $\mathrm{MU}$ in Korea) recounted how she was impressed by a professor's insightful approach in terms of setting a due date, giving students encouragement in submitting their assignments, and providing them with feedback. The professor said that a due date is a "living line" not a "deadline," which astonished Sarang because in a Korean setting, a due date is assumed to be strictly imposed. In Korea, she had rarely received detailed feedback on her reports, and so recollected this novel experience as meaningful. Later, Sarang added that she became more interested in the class because she felt the professor's feedback reflected his willingness to give her his attention. Promoted by the professor's considerate pedagogical guide, Sarang was motivated to engage even more sincerely in the class.

Some Canadian and Korean exchange students illustrated active or passive involvement of local students in class in a very disparate way. Katy (a third-year Canadian student studying Commerce, on exchange at $\mathrm{HU}$ ) pointed to the presence of inactive Korean students in class despite the professors' encouragement to participate. She was curious why Korean students did not even ask simple questions, which is common in Canadian classrooms. Shinbi, a fourth year Economics student from $\mathrm{HU}$ studying at $\mathrm{CU}$, related her Korean academic experiences in in a way that may partially explain why, as Katy observed, Korean students do not seem to be actively involved during class:

If a student asks questions during a class in Korea, most classmates stare at the student thinking, "Why do you ask such kind of (silly or impolite) question?" and also some professors tend to consider questions to be a challenge of their authority or professionalism. So it's hard to pose questions during class in Korea.

According to Shinbi, Korean students and some Korean professors seem to have different perspectives toward students' questions, compared with professors and students in Canada. Given the hierarchical relationship between a professor and a student in Korea, if students want to raise questions in the middle of a class, those questions should be important enough to interrupt a professor's lecture and take other students' precious time and attention. Moreover, in the Korean pedagogical contexts, when questions are raised, it is usually by the professor's invitation, and to reaffirm that students understand the professor's lecture, not to facilitate further discussion. When students pose questions without the professor's solicitation or encouragement, it could embarrass these professors and cause them to lose face. These norms and practices have created a teacheroriented academic tradition in Korea. This Korean academic culture does not encourage Korean students to be creative and audacious but rather makes them docile subjects. Accordingly, before Korean students ask questions in class, they tend to think long and hard about whether their questions are really worthwhile enough to interrupt class and to take others' time. Due to this aspect of Korean culture, some Korean professors may interpret impromptu questions as impolite; they do not encourage this practice and tend to respond to these questions negatively, which lessens students' motivation to ask them. 
In addition, saving face, which is referred to 체면 (chaemyon) in Korean, is a prevalent phenomenon in the Korean classroom atmosphere (G. Lee 2009). This saving face culture is associated with the Korean propensity of recognition of self in relation to others, in particular in-group members; hence, saving face is critical in Korean society in terms of "inclusion and approval of one's social and relational status one possesses and perceives" (Shim, Kim and Martin 2008, 73). Furthermore, since many Korean students had been accustomed to listening carefully and accurately taking notes in their primary and secondary schools, even when they were exchange students some still seemed hesitant to be involved in interactive communication such as raising questions.

\section{Pedagogical relationship with professors}

When the nine exchange students actively interacted with professors at the host institution, they tended to recollect their foreign education experience positively and said they felt friendly toward faculty members. Shinbi assumed that it was difficult to meet professors face to face in her home country Korea and to communicate with them liberally. Conversely, in Canada she viewed relationships with professors as more close and thus she communicated with them very actively. Meanwhile, Maru (fourth-year Psychology student from MU in Korea) was pleasantly surprised when professors at CU remembered students' names and called on them by name during class, which is very rare in Korean higher education classrooms. This different practice inspired Maru by making him feel respected by professors.

Prior to her departure for Korea, Katy had conceived of Korean professors as "scary" compared to 'friendly' Canadians because Korean language has an honorific form. The Korean language can create distance between young and older Korean people in a way that is not common in English. In a similar vein, Angela (fifth-year Political Science student from CU on exchange at HU) perceived Korean professors as distant because she had to use the Korean honorific form when speaking to them, given their high social status in the Korean academic hierarchy. The Korean discursive practice of calling a professor by adding an honorific suffix, 님 (nim, dear Sir/Madam) creates a vertical relationship and a psychological remoteness between a professor and a student, which is a barrier to relaxed communication. Honorific language is a clear example of Korea's stratified system, which regulates and is closely related to socially defined manners and behavioral codes (Jo 2001). Furthermore, in Korea, professors are highly respected and influential. There is a Korean proverb that says, "Do not step even on the shadow of your teacher." As a result, Angela was hesitant to approach her host country's professors out of a fear of making mistakes, owing to her limited knowledge of Korean culture.

Social imaginaries are not only "a grasp on the norms underlying our social practice" but also "a sense... of what makes these norms realizable" (Taylor 2004, 28). Social imaginaries enable exchange students to understand normative facts as well as to take an ethical view of certain social practices (Taylor 2004). Embedded with different social imaginaries of ethical modes, Korean students interpret strange practices in Canadian academic settings in a negative way. Confucianism requires people to revere authority and lead a disciplined life (Yu and Yang 1994). As such, for Korean students who had been accustomed to a Confucian ethos, classrooms were not seen a space for one to satisfy their appetites, but rather as a place to show respect for teachers' supremacy. Consequently, behaviors such as eating food during class, sitting in a very casual posture, chewing gum, or packing bags very loudly before finishing the class, which may be common practices in Canada, were perceived as impolite by some Korean students.

While these Korean students pointed out these 'impolite' behaviors of students in Canada, Erica (a former exchange student in Psychology who had completed her degree) also noticed an example of "unethical" behavior by a Korean student who placed a bottle of juice on a professor's table, which she interpreted as a bribe. Nonetheless, in the Korean context, putting a beverage on an instructor's table is often assumed to be an expression of a student's gratitude or respect toward the professor. Seemingly similar practices 
are interpreted differently by students depending on their individual contexts and how base their observations (Singh et al. 2007). However, recently Korea enacted a law named the Improper Solicitation and Graft Act, which does not allow people to give even small favors that might be considered a bribe. Therefore, these days students avoid putting a beverage on a professor's table.

\section{Conclusion}

This study demonstrates exchange students' navigations in and between academic spaces of Canada and Korea by portraying each student's perceived, imagined, and lived spaces through their material engagements and academic practices. Exchange students arrive in their host country with different imaginations and expectations, and their academic yearnings and anticipations are based on diverse feelings and perspectives when they are confronted with foreign education environments. When exchange students venture out into a foreign terrain, they decipher unfamiliar practices from their own vantage points and create particular translations of those repertoires. Since they embarked on their journey to the host country inscribed with their own social imaginaries of legitimate practices, their engagements with the foreign site were idiosyncratic, and fused with their personal, cultural, and ideological inheritances.

Transnational space provides these students with new and expanded meanings, yet this foreign arena also creates constraints and challenges, such as having to learn under unfamiliar academic traditions and having to communicate in a foreign language. In the host institution, different perceptions and expectations between professors and exchange students, as well as between domestic students and exchange students, meet and sometimes clash. When there are wide gaps in terms of cultural habits, personalities, and pedagogical values among professors, international students, and local students, collisions occur more frequently and it takes quite some time to find compromises between different views and to narrow the discrepancies. This implies that faculty should try harder to create a more inclusive milieu to understand and embrace different mindsets, cultures, and ideologies of exchange students. Meanwhile, when exchange students experience affirmative care from professors in their host country, they were more satisfied with their academic experience, which fostered their subsequent class involvement. As such, this study also suggests that professors should be more sensitive to each student's cultural background and create culturally "fair" climate trying to understand exchange students' demanding conditions.

In addition, given exchange students' difficulties relating to local students, professors should pay particular attention to providing opportunities for these students to interact with local students and incorporate strategies to facilitate exchange students' participation in class. Students' passive participation in the classroom, including silence instead of full-participation, is an outcome that is co-constructed by professors who are less sensitive to each student' diverse socio-cultural backgrounds and by students who lack the pedagogical norms associated with a foreign institution. Therefore, when teachers intentionally engage both groups, exchange and domestic students will have more chances to practice and experience the host country's academic logics and cultural practices, which eventually contributes to overcoming cultural barriers. To enhance their cultural awareness during their academic exchange, institutional actors should be active in informing exchange students about different cultural perceptions, ethics, and academic traditions. This type of awareness could be fostered from the offices that arrange academic exchange agreements between partnering institutions, perhaps with greater success if faculty are more deeply included in the pre-arrival processes of study abroad programs. 


\section{References}

Al-Haquea, Rashed. "University Internationalization, Immigration, and the Canadian Dream: How Federal Citizenship Immigration Legislation Marginalizes International Graduate Students." Journal of Comparative \& International Higher Education 9 (2017): 5.

Altbach, Philip G., and Ulrich Teichler. "Internationalization and exchanges in a globalized university." Journal of Studies in International Education 5, no. 1 (2001): 5-25.

Brodin, Jane. "Education for global competencies: An EU-Canada exchange programme in higher education and training." Journal of Studies in International Education 14, no. 5 (2010): 569-584.

Doyle, Stephanie, Philip Gendall, Luanna H. Meyer, Janet Hoek, Carolyn Tait, Lynanne McKenzie, and Avatar Loorparg. "An investigation of factors associated with student participation in study abroad." Journal of Studies in International Education 14, no. 5 (2010): 471-490.

Clandinin, D. Jean and F. Michael Connelly Narrative inquiry: Experience and story in qualitative research. (2000). San Francisco: Jossey-Bass Publishers.

Grbich, Carol. Qualitative data analysis: An introduction. (2013). San Francisco: Sage.

Gubrium, Jaber F., and James A. Holstein. Analyzing narrative reality. (2009). San Francisco: Sage.

Holstein, James. A., and Jaber F. Gubrium. The self we live by: Narrative identity in a postmodern world. (2000). New York: Oxford University Press.

Hudzik, John K. Comprehensive internationalization: Institutional pathways to success. (2014). New York: Routledge.

Jo, Hye-young. "'Heritage' Language Learning and Ethnic Identity: Korean Americans' Struggle with Language Authorities." Language Culture and Curriculum 14, no. 1 (2001): 26-41.

Korean Educational Development Institute. Exchange program participants between Korean universities and universities in foreign countries. (2015). Seoul, Korea: KEDI.
Lee, Given. “Speaking up: Six Korean students' oral participation in class discussions in US graduate seminars." English for Specific Purposes 28, no. 3 (2009): 142-156.

Lee, Hye-Jung. What can SNU A+ students do? (2014). Seoul: Dasan Edu.

Lee, Suji. The meaning of exchange student experience from the perspectives of college student development. (2014). Unpublished master's thesis, Korea University, Seoul, Korea.

Organization for Economic Co-operation and Development. Education at a glance 2013: OECD indicators. (2013). Paris, France: OECD publications.

Park, So Jin. Reconsidering Korean culture and society and seeking self identity in the world: Short-term study abroad motivation and experiences. Comparative Korean Studies 18, no. 1 (2010): 217 262.

Pike, Graham, and Mackenzie Sillem. "Study Abroad and Global Citizenship: Paradoxes and Possibilities." In The Palgrave handbook of global citizenship and education, pp. 573-587. (2018). London: Palgrave Macmillan.

Polkinghorne, Donald E. Narrative knowing and the human sciences. (1988). Albany, NY: SUNY Press.

Polkinghorne, Donald E. "Narrative configuration in qualitative analysis." International journal of qualitative studies in education 8, no. 1 (1995): 523.

Razack, Narda. "A critical examination of international student exchanges." International Social Work 45, no. 2 (2002): 251-265.

Rhodes, Gary, Lisa Loberg, and Ann Hubbard. "Historical, philosophical, and practical issues in providing global learning opportunities through study abroad." New Directions for Student Services 2014, no. 146 (2014): 5-13.

Riessman, Catherine Kohler. Narrative methods for the human sciences. (2008). San Francisco.

Rizvi, Fazal. "Imagination and the globalisation of educational policy research." Globalisation, Societies and Education 4, no. 2 (2006): 193-205. 
Rizvi, Fazal, and Bob Lingard. Globalizing education policy. (2010). London: Routledge.

Shim, Theresa Youn-ja, Min-Sun Kim, and Judith N. Martin. Changing Korea: Understanding culture and communication. Vol. 10. (2008). Peter Lang.

Singh, Michael, Fazal Rizvi, and Mona Shrestha. "11 Student mobility and the spatial production of cosmopolitan identities." In Spatial theories of education: Policy and geography matters, pp. 195214 (2007). New York: Routledge.

Take, Hiroko, and Ai Shoraku. 'Universities' expectations for study-abroad programs fostering internationalization: Educational policies." Journal of Studies in International Education 22, no. 1 (2018): 37-52.

Taylor, Charles. Modern social imaginaries. (2004). Duke University Press.

Zappa-Hollman, Sandra. "The academic literacy socialization of Mexican exchange students at a Canadian university." (2007). Unpublished PhD dissertation, The University of British Columbia. 